\title{
An integrated reconstruction of the early Pleistocene palaeoenvironment of Homo erectus in the Denizli Basin (SW Turkey)
}

Lea Rausch ${ }^{\text {a,j*}}$, Hülya Alçiçek ${ }^{b}$, Amélie Vialet ${ }^{c}$, Nicolas Boulbes ${ }^{c}$, Serdar Mayda ${ }^{\text {d }}$, Vadim V. Titov ${ }^{\mathrm{e}}$, Marius Stoica ${ }^{\mathrm{a}}$, Sylvain Charbonnier ${ }^{\mathrm{f}}$, Hemmo A. Abels ${ }^{\mathrm{g}}$, Alexey S. Tesakov ${ }^{\mathrm{h}}$, Anne-Marie Moigne ${ }^{\mathrm{c}}$, Valerie Andrieu-Ponel ${ }^{\mathrm{i}}$, Dario De Franceschi ${ }^{\mathrm{f}}$, Thomas A.

Neubauer $^{\mathrm{j}, \mathrm{k}}$, Frank P. Wesselingh ${ }^{\mathrm{k}}$, M. Cihat Alçiçek ${ }^{\mathrm{b}}$

${ }^{\text {a } U n i v e r s i t y ~ o f ~ B u c h a r e s t, ~ F a c u l t y ~ o f ~ G e o l o g y ~ a n d ~ G e o p h y s i c s, ~ B a l c e s c u ~ B d . ~ 1, ~} 010041$

Bucharest, Romania

${ }^{\mathrm{b}}$ Pamukkale University, Department of Geology, 20070 Denizli, Turkey

c Muséum National d'Histoire Naturelle, Département Homme \& Environnement, UMR 7194, UPVD-CERP, avenue Léon Jean Grégory, 66720 Tautavel, France

${ }^{\mathrm{d}}$ Ege University, Department of Biology, 35100, Izmir, Turkey

e Southern Scientific Centre RAS, Chekhov str., 41, 344006 Rostov-on-Don, Russia

${ }^{\mathrm{f}}$ Muséum National d’Histoire Naturelle, Département Origines \& Evolution, UMR 7207

CR2P, CNRS, Sorbonne Université, 8 rue Buffon, 75005 Paris Cedex, France

${ }^{g}$ Delft University of Technology, Faculty of Civil Engineering and Geosciences, Stevinweg 1, 2628 CN, Delft, The Netherlands

${ }^{\mathrm{h}}$ Geological Institute of the Russian Academy of Sciences, Pyzhevsky 7, 119017, Moscow, Russia

${ }^{\text {i } I n s t i t u t ~ M e ́ d i t e r r a n e ́ e n ~ d e ~ B i o d i v e r s i t e ́ ~ e t ~ d ’ E ́ c o l o g i e ~ M a r i n e ~ e t ~ C o n t i n e n t a l e ~(I M B E), ~}$ Bâtiment Villemin, BP 80, 13545 Aix-en-Provence Cedex 4, France 
${ }^{\mathrm{j}}$ Department of Animal Ecology \& Systematics, Justus Liebig University, Heinrich-Buff-Ring 26-32 IFZ, 35392 Giessen, Germany

${ }^{\mathrm{k}}$ Naturalis Biodiversity Center, P.O. Box 9517, 2300 RA Leiden, The Netherlands

* Corresponding author. E-mail address: leanrausch@gmail.com (L. Rausch).

\ Corresponding editor: Emmanuel Fara.

\section{Abstract}

The early Pleistocene travertines from Kocabaş in the Denizli Basin (SW Turkey), from which the only known Homo erectus from Anatolia derives, are covered by a succession of lake deposits. So far, the taphonomic history of the site has precluded a detailed palaeoecological analysis. This paper details the sedimentary succession and palaeoenvironmental conditions by analysing the micro- and macropalaeontological species compositions. These data provide direct evidence of the opportunities and limiting factors of the environment inhabited by hominins during the early Pleistocene. Four distinctive lithostratigraphic units are recognized in the Quaternary succession, consisting of: Lower Travertine, Lower Conglomerates, Upper Travertine, and Upper Conglomerates. These units correspond to an alternation of lacustrine limestone, fluvial-lacustrine siliciclastic deposits and subaerially precipitated travertine accumulations. The age of the succession is constrained by cosmogenic nuclide concentration, palaeomagnetic measurements and large mammal biostratigraphy which suggest deposition occurred between $~ 1.6$ and 1.2 Ma. The travertine succession contains a moderately diverse macromammal fauna, including Homo erectus, decapod crustaceans and leaf imprints. The herbivore association likely dwelled in a mixed landscape during temperate and humid climatic conditions, supported by negative $\delta^{18} \mathrm{O}$ values from analysed gastropod and bivalve shells. The presence of an anomalohaline lake is indicated by an abundant and well-preserved ostracod community, consisting of alkaline tolerant taxa and freshwater genera further supported by the presence of cardiid bivalves.

Keywords:

Southwestern Anatolia

Denizli Basin 
Homo erectus

Calabrian

Palaeoecology

\section{Introduction}

The detailed reconstruction of past environments preserved in the fossil record plays an important role in understanding the interactions of our ancestors with the surrounding landscape and, even more importantly, how the environment has influenced our evolutionary past. In order to comprehend the environmental context through time, palaeoanthropology reaches far beyond the discovery and description of human fossils and stone tools (Kingston, 2007). As part of an ecosystem, early humans only played a subordinate role in a much larger framework, consequently demanding a highly interdisciplinary approach in order to understand the driving forces behind adaptive shifts in our ancient history. The hominin dispersal out of Africa has received considerable attention with sites in both Africa and Eurasia having been subject to a variety of dating techniques in order to establish a reliable chronostratigraphic framework (Swisher et al., 1994; Oms et al., 2000; Sémah et al., 2000; Falguères, 2003; Voinchet et al., 2004; Carbonell et al., 2008; Messager et al., 2009; Zhu et al., 2018).

The Kocabaş site in SW Anatolia (Turkey) is considered a major landmark of hominin dispersal, providing an opportunity to study the way the Old World was populated (Kappelman et al., 2008; Vialet et al., 2018). However, its palaeoecological context is in need of further investigations. Here, we provide the reconstruction of the palaeoecological setting of the early Pleistocene Homo erectus. Its fragmentary calvaria was recovered from a travertine quarry near the village of Kocabaş inside the Denizli Basin in 2002 (Fig. 1(A)). The Denizli Basin is located among one of the most active extensional areas in the World (Westaway, 1993) and was controlled by a NE-trending fault system during the Quaternary that led to the deposition of massive travertine formations.

The fossil hominin, which represents the first Homo erectus specimen discovered in Turkey (Kappelman et al., 2008; Vialet et al., 2012; Alçiçek, 2014), was found ex-situ but could be assigned to the fossiliferous travertine unit (i.e., Upper Travertine described in Lebatard et al., 2014a) present in the Killik hill of the Ballık area (Fig. 1(B)), in the eastern part of the Denizli Basin. The travertine unit is currently mined from different sides. Within the Faber quarry, which covers the area including the Killik hill, successive exposures have 
been available for decades, providing the means to study the palaeoecological and geological context of this Homo erectus specimen. Based on cosmogenic nuclides $\left({ }^{26} \mathrm{Al} /{ }^{10} \mathrm{Be}\right)$ and palaeomagnetic measurements the burial age of the sedimentary succession was estimated to cover a range between $\sim 1.6$ and 1.2 Ma (Lebatard et al., 2014a, b). Furthermore, macromammal findings most likely derived from the same level as the Homo erectus calvaria were assigned to the late Villafranchian, suggesting the deposition of the Upper Travertine likely during 1.4-1.2 Ma (Boulbes et al., 2014). The travertine unit is onlapped by a succession of fluvio-lacustrine deposits (i.e., Upper Conglomerates) that contain sedimentary and fossil evidence providing an important background in relation to the depositional setting and environment.

The morphological pattern of the partial skullcap from Kocabas is not far from the Asian Homo erectus (Vialet et al., 2012, 2014) but more closely resembles the African ones and evidences a distinct evolutionary link from the Dmanisi fossils in Georgia (Kappelman et al., 2008; Vialet et al., 2018). In a way, such results show the key position of Turkey within the Old World, at the crossroads between Africa, Asia and Europe. On that ground, we present here a combined palaeontological and sedimentological study of the Kocabaş travertine and fluvio-lacustrine succession.

\section{Settings}

\subsection{Geological and climatic setting}

The Denizli Basin is located in southwestern Anatolia (Turkey) (Fig. 1). The region has been an active extensional tectonic province since the early Miocene (Şengör and Yılmaz, 1981; Bozkurt, 2001, Ten Veen et al., 2009). The Denizli Basin is $50 \mathrm{~km}$ wide and $70 \mathrm{~km}$ long and is delimited by NW- and SE-trending fault systems. It hosts basin-fill successions that reach up to $1300 \mathrm{~m}$ in thickness and consist of alluvial-fan, fluvial and lacustrine deposits (Şimşek, 1984; Alçiçek et al., 2007, 2015; Sun, 1990; Konak and Şenel, 2002; Konak, 2002; Koçyiğit, 2005; Kaymakçı, 2006).

The basin experienced a two-phase tectonic evolution: (i) incipient/initial supradetachment basins developed (Lips et al., 2001; Sözbilir, 2005) during the early-middle Miocene, and (ii) subsequent high-angle faults cross-cut older structures drove the basin evolution. The present basin configuration developed since the late Miocene (Kaymakç1, 2006). During the latter phase, diffuse geothermal activity induced extensive travertine formation that can be found at several locations inside the basin (Şimşek, 1984; Brogi et al., 2014, 2016; Capezzuoli et al., 2018). 
During the Quaternary, the Denizli Basin topography has been controlled by the activation of a WNW- ESE trending fault system composed of the Pamukkale, Akköy and Tripolis fault segments (Altunel and Hancock, 1993a, 1993b; Altunel, 1994; Hancock et al., 1999; Çakır, 1999; Alçiçek et al., 2007; Brogi et al., 2014; Capezzuoli et al., 2018; Alçiçek et al., 2019a, b). Major travertine deposits developed along these fault segments. Thermal springs are still active throughout the Denizli Basin today, inducing travertine precipitation, notably along the north-eastern basin margin (Alçiçek, 2010; Alçiçek and Alçiçek, 2014). During the Neogene and Quaternary, the basin hosted a variety of flora and fauna and possibly functioned as an interregional migration corridor (Alçiçek, 2010). Especially in the eastern part (around the town of Kocabaş), extensive Quaternary travertine deposits are being quarried for commercial purpose and have yielded a variety of macromammal remains (Boulbes et al., 2014).

Presently, the study area is located in the transition zone between the forested high Western Taurus Mountains and the Alpine Orogen that extends west-east across southern Anatolia in the south, and the arid steppe highland of central Anatolia to the northeast (Robert and Wright, 1993). The mountain areas are covered by Mediterranean forest dominated by pine and cedar but also show a broad overlap of European and Turko-Iranian floras (Ansell et al., 2011; Davis, 1965; Schweizer, 1975).

The climate in the region is characterized by hot, dry summers (average $22.4^{\circ} \mathrm{C}$ ) and cool, wet winters (average $10.6^{\circ} \mathrm{C}$ ). The mean annual precipitation for the region is $566 \mathrm{~mm}$ per year (Turkish State Meteorological Service, 2018). The barometric depression that forms near the Aegean coast or around Cyprus and moves eastwards towards the Caspian Sea region controls the precipitation within Anatolia (Schweizer, 1975). Glaciation during the Pleistocene within Anatolia was limited to the higher mountain peaks (Atalay, 1996), leaving the lowlands open. Quaternary climatic data from Lake Eğirdir, located within the northern marginal zone of the Taurus Mountains, evidenced a shift from warm-humid phases containing pronounced drier conditions, to a colder climate with alternating higher and lower humidity during the early to late Pleistocene (Cita, 1982; Akay et al., 1985).

\subsection{Palaeoanthropological setting}

When the Kocabaş skullcap (Fig. 2) was discovered in 2002 it consisted of three fragments, belonging to the same young individual: (i) the left part of the frontal bone and the fragment of the left parietal bone in anatomical connection; (ii) the right parietal fragment; and (iii) the right part of the frontal bone (Kappelman et al., 2008; Vialet et al., 2012). For re- 
establishing the anatomical connection between the three cranial parts and to compensate the missing parts, combined CT data and 3D imagining techniques where used to generate a reconstruction of the calvaria (Fig. 2). It enabled morphological and metrical comparisons between the Kocabaş specimen and other selected hominins from Africa, Asia and Europe (Vialet et al., 2012). This study indicated a close morphological similarity, regarding the size and anatomy of the anterior part of the frontal bone, between the Kocabaş calvaria and the African specimens ER3733 and OH9 as well as to the Chinese specimens from Zhoukoudian L-C (Vialet et al., 2014). The calvaria from Kocabaş therefore can be considered as the oldest Homo erectus that has settled so far west in Asia. However, unlike the fossils from China, the Kocabaş calvaria does not display any sagittal keel and shows a shorter frontal bone.

Finally, based on a cladistic analysis, it seems closer to the African Homo erectus and less to the archaic Dmanisi fossils, evidencing another evolutionary history and maybe an additional expansion wave outside Africa (Vialet et al., 2018). Even without having the opportunity for a strict comparison with the European record (the oldest hominin fossil is a mandible from Atapuerca-Sima del Elefante in Spain dated to 1.2 Ma), we can suggest that the Kocabaş specimen potentially played a role in such peopling, based on its geographical and chronological position.

\section{Material and methods}

The stratigraphic overview has been compiled from observations in the southern corner of the Faber quarry (Fig. 3) and the adjacent western wall in November 2013, April 2015, and April 2018. The general architecture was gathered from distance observations of the layers exposed in mostly vertical walls and supplemented with inspection of accessible intervals along the western wall.

The complete section is composed of four units (Fig. 3), consisting of (from bottom to top): (i) Unit 1, Lower Travertine; (ii) Unit 2, Lower Conglomerates; (iii) Unit 3, Upper Travertine; and (iv) Unit 4, Upper Conglomerates (Lebatard et al., 2014a; Khatib et al., 2014). It is worth noting that the terms used here are commercially introduced names and do not refer to the correct lithological designation. In this study, we focus on the fossil associations from the uppermost two units (Fig. 4).

The deposits of Unit 3 (Upper Travertines) contain early Pleistocene mammal fossils including the Homo erectus finding and plant remains (Vialet et al., 2012, 2014, 2018; Boulbes et al., 2014; Lebatard et al., 2014a, b). The mammal remains are usually found ex situ, during the cutting process of large travertine blocks in the factories surrounding the 
quarries. It is often difficult to free them from their strongly consolidated host rock and due to the circumstances of their discovery during the extraction process, they are often poorly preserved, which limits the scope of morphological observations and biometric studies, and thus taxonomic conclusions. The claim that the vertebrate fauna comes from the Upper Travertines is supported by two arguments:

- consistent reporting by quarry owners and workers that is in agreement with our observations and interpretations. The porous appearance and the sub-aerial depositional setting of the Upper Travertines stands in contrast to the compact, fossil barren and subaqueous deposited Lower Travertines;

- most mammal findings were reported during the 1990s and the early 2000s, an interval during which the Upper Travertines were predominantly excavated, as opposed to the later exploitation of the Lower Travertines.

The Upper Travertine unit is actively quarried and forms an ancient hill structure with height differences of $c a$. $20 \mathrm{~m}$. This unit is onlapped by a series of mixed carbonatesiliciclastic deposits (Upper Conglomerates) that yielded the herein detailed ostracod and mollusc fauna. The sampled section (Fig. 3(B-E)) is located at the northern end of the western

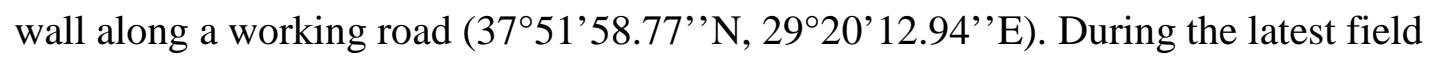
campaign in 2018, additional samples were taken from an exposure located at the eastern flank of the Killik hill (3751'47.80’'N, 29²0'16.07’'E), in order to examine the lateral facies extension.

Fifteen ostracod samples derived from clay intercalations from two localities inside the quarry were processed using standard micropalaeontological methods outlined in Stoica et al. (2013). To improve disaggregation, samples were boiled with sodium carbonate before being subsequently washed and sieved over a battery of three sieves (500-125-63 $\mu \mathrm{m})$. The appearance of both juvenile and adult specimens, prove the in-situ character of the assemblage. Many of the ostracod carapaces were internally and externally covered by a more or less pronounced thin layer of secondary calcite. The recrystallization is considered to be post-depositional, induced by calcium carbonate rich water that circulated inside the sediment after burial.

The shells of gastropods and bivalves obtained from the same interval are predominantly dissolved and preserved as imprints and casts. The rare preservation of original shells complicates identifications and the assignment to the taxa reported below is subject to some uncertainty. Oxygen and carbon stable isotope analyses were performed on four mollusc samples possessing original shell material. The stable isotope analyses $\left(\delta^{18} \mathrm{O}\right.$ and $\left.\delta^{13} \mathrm{C}\right)$ were 
carried out at the SIRFER Laboratory at Utah University (USA) according to Kim et al.'s (2007) method. About $0.5 \mathrm{mg}$ of powdered shell was dissolved in orthophosphoric acid at $50^{\circ} \mathrm{C}$. The evolved $\mathrm{CO}_{2}$ was purified and run off-line on a FinniganMat 251 mass spectrometer. The $\delta^{18} \mathrm{O}$ and $\delta^{13} \mathrm{C}$ compositions are reported in the \%o notation with respect to the V-PDB standard, using NBS 19 as a primary reference. Analytical precision of an internal standard was \pm 0.10 and $\pm 0.06 \%$ o $(1 \sigma)$ for $\delta^{18} \mathrm{O}$ and $\delta^{13} \mathrm{C}$, respectively, for the measuring period.

\section{Results}

\subsection{Sedimentology}

The section is ca. $95 \mathrm{~m}$ thick and located in the southern corner of the Faber quarry. It is composed of four units consisting of lacustrine and terrestrial carbonate deposits and siliciclastic accumulations. In the geochronological study of Lebatard et al. (2014a), the units were defined as follows: Lower Travertine, Lower Conglomerates, Upper Travertine, and Upper Conglomerates (Figs. 3, 4).

Unit 1 (Lower Travertine) is composed of a massive, mm-scale laminated, light beige limestone that is $c a .16 \mathrm{~m}$ thick. Laminae are parallel, with horizontal and gently undulating profiles. Individual lamina thickness ranges from micrometres to $2 \mathrm{~mm}$ thick. The finelylaminated facies consists of a succession of light-coloured laminae, each 0.1-2.0 mm thick, made of elongated calcite crystals, and dark-coloured calcite laminae (50 to $500 \mu \mathrm{m}$ thick) made of smaller anhedral crystals. The detrital components are very low ( $3 \%)$ in proportion to the calcium carbonate of the limestone, which encompasses $\sim 97 \%$ of the unit (Khatib et al., 2014). The deposits further contain both sub-horizontal and sub-vertical cracks that are considered to be triggered tectonically. In some cases, these few centimetres wide cavities are filled with secondary calcite.

Unit 2 (Lower Conglomerates) consists of an alternation of clast-supported, reddishbrown conglomerates, coarse sand and chalky limestone beds. This unit is ca. $12 \mathrm{~m}$ thick and dips gently from west to east. The conglomerate contains fine gravel that is in average $>2 \mathrm{~mm}$ (70\%), rounded pebbles and limestone boulders. The pebbles are made of quartz and metamorphic material and originated from the surrounding Mesozoic and Neogene formations (Khatib et al., 2014). The thickness of this layer can reach up to $2 \mathrm{~m}$ and is overlain by coarse sand, containing 65\% calcite, 29\% quartz, 3\% minerals of metamorphic origin and volcanics, $2 \%$ feldspars, and 1\% quartzite sandstone (Khatib et al., 2014). The sandy layer is overlain by a thin layer of chalky limestone up to $30 \mathrm{~cm}$. 
Unit 3 (Upper Travertine) is ca. $50 \mathrm{~m}$ thick and composed of light beige laminated limestone at the base and porous white travertine deposits at the top. Some of the cavities that are lined with calcite in the form of stalagmites and stalactites reach slightly over one metre in length and are concentrated within the travertine deposits towards the top of the unit. Within this interval, a thin layer of intercalated marl is present. This actively quarried unit shows clear structures corresponding to former travertine terraces including some overhanging pool, rims and scarps. Scanning electron microscope analysis of thin sections carried out by Khatib et al. (2014) showed the presence of fine silica needles and bacteria. Therefore, the formation of this travertine unit can be assigned to a chemical and biochemical origin. Similar to Unit 1 , this unit shows a low concentration of detrital components in proportion to the calcium carbonate content.

Unit 4 (Upper Conglomerates; Figs. 3(B-E), 4) consists of ca. $16 \mathrm{~m}$ of interbedded carbonate sands, stratified clay, silts and planar-parallel cross-stratified mixed carbonatelithoclastic conglomerates containing a shelly fauna. This unit progressively onlaps onto Unit 3 and starts with sandy-silty conglomerate containing medium-sized pebbles, followed by an interval of fine laminated clay-and siltstones. The next interval consists of finely laminated siltstone, containing carbonate, pebble-sized concretions at the top. The herein described ostracod fauna is evaluated from samples processed from this interval. The overlaying lithoclastic conglomerates host a rich and in most cases recrystallized mollusc fauna at the base that is subject to taxonomic investigations. The layer containing the mollusc assemblage was further used to correlate the eastern exposure of the Upper Conglomerates. The conglomerate layer is followed by finely laminated siltstones, from which additional micropalaeontological samples were gathered. The uppermost part of Unit 4 consists of stratified, well-sorted sand deposits that are intercalated by silty layers.

\subsection{Invertebrate palaeontology}

\subsubsection{Ostracods}

The ostracods, derived from the fine-grained intercalations of the Upper Conglomerates, are highly abundant and relatively well preserved. We identified 16 species belonging to 9 genera. The assemblage is represented by a mixture of freshwater (species of Candona, Prinocypris, Cypria, Lineocypris and Darwinula) and oligohaline to mesohaline forms (species of Cyprideis, Tyrrhenocythere, Loxoconchissa (Loxocaspia) and Amnicythere).

Noded Cyprideis torosa specimens appear in great abundance in all collected samples. This species is one of the most common shallow-water ostracods, known for its tolerance of 
wide ranging salinities (Boomer et al., 2017). It has been described from freshwater to fully marine and even hypersaline waters (over 60\%o) (Meisch, 2000). Salinities ranging between 2 and $16.5 \%$ are reported to offer the optimal conditions for population development (Meisch, 2000; Wagner, 1964). At water salinities below 6\%, the number of noded (phenotypic tubercles) bearing specimens increases markedly (Vesper, 1972). The relationship between variable noding and strong fluctuations in salinity and/or $\mathrm{Ca}^{2+}$ or $\mathrm{Na}^{+}$concentration in the ambient water has first been reviewed by Kilenyi (1972). Great bursts of abundance can occur at times of changes from fresh to alkaline or saline conditions, often resulting in the presence of monospecific assemblages. This leads to the conclusion that large Cyprideis fossil populations in alkaline or evaporitic sequences devoid of diverse faunal range of typical marine or freshwater habitats. The onset of such conditions is well known and also has been described from rapid speciation of Cyprideis in marginal marine environments of the Paratethys (Krstić, 1985). Apart from the noded Cyprideis torosa, a significantly smaller Cyprideis sp. 1 (Fig. 5(M, N)) was found, which does not possess tubercles and shows little surface ornamentation.

The genus Tyrrhenocythere has a similar ecological preference as C. torosa, supporting the presence of an alkaline palaeolake. We identified three species of Tyrrhenocythere that are differentiated based on their ornamentation. The most common species is Tyrrhenocythere pontica (Fig. 5(O, P)), showing a well-developed net-type ornamentation and a pronounced ventral crest. The other two species show a simplification of the ornamentation pattern that becomes mainly pitted with minor occurring concentric crests or finer reticulation towards the anterior and posterior ends as it is the case in T. ex. gr. bailovi (Fig. 5(Q, R)) and an almost vanishing smooth to finely pitted surface with poorly visible reticulation in the anterior and posterior end in Tyrrhenocythere sp. 1 (Fig. 6(A, B)).

The occurring Loxoconchissa species show variations in the nature and degree of their external ornamentation, which ranges from a clear net-type reticulation in Loxoconchissa (Loxocaspia) aff. reticulata (Fig. 6(I-N)) to a much coarser and irregular reticulation and strong round tubules pores in Loxoconchissa (Loxocaspia) sp. (Fig. 6(O-T)). Both species show a remarkable sexual dimorphism. The male carapace of Loxoconchissa (Loxocaspia) aff. reticulata is slightly more elongated and shows a broadly flattened anterior area and a well pronounced tubercle in the posterior part. The male carapace of Loxoconchissa (Loxocaspia) sp. shows prominent tubercles in the posterior-central part of the valve that is particularly impressive in dorsal view. The family Loxoconchidae in general is well known from both brackish fossil taxa as well as living genera (Faranda et al., 2007). 
The genus Amnicythere is represented by Amnicythere aff. pediformis (Fig. 6(C-E)) and Amnicythere multituberculata (Fig. 6(F-H)). Living representatives of A. multituberculata were described by Yassini (1986) from the central and southern Caspian Sea Basin at salinities of 11.5-18.25\%, supporting the presence of an anomalohaline setting.

The cypridoid ostracods, comprising mainly smooth freshwater forms, are represented by Candona neglecta, Prinocypris zenkeri, Lineocypris sp., Cypria sp., and Darwinula stevensoni (Fig. 5(A-J)). All species inhabit a wide range of aquatic habitats like ponds, rivers and lakes. In the latter setting, they have been described from mainly the shallow littoral zone (Meisch, 2000). The co-occurrence of typical anomalohaline species and cypridoid ostracods suggests that the freshwater forms can also survive in slightly higher alkaline conditions.

\subsubsection{Molluscs}

A moderate diverse mollusc assemblage has been obtained from the same interval. The preservation of the original shell layer is scarce and moulds or internal casts are numerous. Shells were mostly found in concentrations that are sorted by size and shape. Together with the associated imbricated flat pebbles, these appear to be shore-type shelly accumulations. Since the limited preservation hampers precise identifications and counting, we report qualitative observations and semi-quantitative abundances. The assemblage consists of at least seven species of gastropods and two species of bivalves. The majority of specimens can only be identified at a (sub)family or genus level, but some resemble species living in Anatolia today.

Within the gastropod fauna, Theodoxus sp. exhibits quite a variability of colour patterns (Fig. 7(A-E)). Determination of species is difficult, however these patterns often vary intraspecifically and are sometimes linked to environmental parameters (Zettler et al., 2004; Glöer and Pešić, 2015). Melanopsis sp. resembles M. buccinoidea (Olivier, 1801) known from present-day Turkey, but the poor preservation and feature-less shell preclude a more precise determination (Fig. 7(F-H)). The identification of Bithynia cf. pseudemmericia Schütt, 1964 is based on a single specimen exhibiting the typically reflected outer lip (Fig. 7(I-J)), which is unique for the genus. The other casts of Bithynia sp. (Fig. 7(L-Q)) may belong to the same species. The single specimen of Falsipyrgula cf. carinata Radoman, 1973 shows the characteristic keel slightly below the centre of the whorl (Fig. 8(G-H)). The specimen also resembles F. osmana (Bukowski, 1930) sensu Schütt and Yıldırım (1999), but the original concept of that species remains dubious for Bukowski (1930) provided only a short description but no size information or illustrations. Other species of Falsipyrgula differ by 
their high spires or the presence of more than one keel (Schütt and Y1ldırım, 1999). The individuals here attributed to Islamia show some variability in shape, specifically the relationship between spire height and width (Fig. 8(A-J)). The slender specimens closely resemble Islamia pseudorientalica Radoman, 1973, the broader ones agree more with $I$. anatolica Radoman, 1973. Both species co-occur and are only known from their type locality, the Kırkgöz springs (Antalya province). Perhaps the two species are synonymous, but examination of more extant specimens and molecular data are required to test this hypothesis. Together with them occurs a third species of Islamia, I. bunarbasa (Schütt, 1964), which differs from the present specimens in its distinctly higher spire. Two species of high-spired Hydrobiidae are found in the Kocabaş material (Fig. 8(L-S)), but the lack of characteristic features does not allow identification of the genus or species. Hydrobiidae sp. 1 resembles in general outline a number of high-spired Graecoanatolica species currently living in the region (Schütt, 1964, Radoman 1983; Kebapçı et al., 2012), such as the very slender G. pamphylica (Schütt, 1964).

Bivalve remains are rare in the Kocabaş fauna. A single fragment of a Lymnocardiinae is present (Fig. 8(T)), yet without any possibility to identify a genus or species. Additionally, few fragments of a slender Dreissena sp. are found (Fig. 8(U-X)). The apparent lack of a well-developed keel suggests it is a representative of the Dreissena rostriformis group.

The mollusc fauna as a whole is dominated by Palearctic taxa, most of which are common in Anatolia today. The gastropod fauna is dominated by Bithynia, Islamia and unidentified hydrobiids. A similar extant community is found in the Kirkgöz springs north of Antalya, where Bithynia pseudemmericia, Islamia anatolica and I. pseudorientalica co-occur with Graecoanatolica pamphylica and Theodoxus altenai Schütt, 1965. The interconnected spring ponds offer clear, slowly running water that are up to $3 \mathrm{~m}$ deep, rich in vegetation and have average temperatures between 14.6 and $16^{\circ} \mathrm{C}$ (Güçlü, 2003; Glöer and Rähle, 2009). Generally, Bithynia pseudemmericia dwells today in different types of habitats in SW Turkey, including springs, lakes and ponds (Kebapçı and Yıldırım, 2010). Islamia species are typical of springs and subterranean waters, but occasionally also occur in rivers and lakes (Bodon et al., 2001, Arconada and Ramos, 2006; Radea et al., 2017). The presence of Theodoxus in our samples suggests rough stony substrate, as it requires to digest the algae it grazes on (Glöer, 2002; Welter-Schultes, 2012). Nothing is known about the ecology of Falsipyrgula carinata, which is today endemic to its type locality near Kıreli in Lake Beyşehir. The species was found in Quaternary deposits of the Konya Basin, located east of the lake (Schütt, 1991). 
The bivalve Dreissena is an epifaunal filter feeder dwelling on hard substrates in rivers, estuaries and lakes from freshwater to mesohaline conditions down to depths of over 130 m (Therriault et al. 2004; Orlova et al., 2005; Welter-Schultes, 2012; Cummings and Graf, 2015). Lymnocardiinae occur in a wide range of well-oxygenated habitats in lagoons, coastal lakes or river mouths, and are typical of oligohaline to mesohaline conditions; some species occasionally also extend into freshwater (Kijashko in Bogutskaya et al., 2013; Albrecht et al., 2014). As (semi-)infaunal suspension feeders they are bound to soft sediments (Wesselingh, 2007; Popa et al., 2012; Albrecht et al., 2014).

Notably lacking are taxa usually restricted to fresh water such as unionoid and sphaeriid bivalves, and planorbid and lymnaeid gastropods. The mollusc assemblage as a whole suggests two different origins: spring environments (with Bithynia, Islamia, Theodoxus, and perhaps Falsipyrgula, Hydrobiidae sp. 1 and Melanopsis) and a probably oligohaline lake (with Dreissena and Lymnocardiinae sp.).

The $\delta^{18} \mathrm{O}$ values of mollusc shells typically lie between -7.24 and $-5.97 \%$ PDB (mean $=-6.64 \%$ PDB) and $\delta^{13} \mathrm{C}$ values between $c a$. -0.06 and $+0.82 \%$ o $\mathrm{PDB}$ (mean $=+0.36 \%$ PDB). The negative $\delta^{18} \mathrm{O}$ isotope ratios of mollusc shells indicate a flux of isotopically light, ${ }^{18} \mathrm{O}$-depleted meteoric water (Anadón et al., 2008; Leng and Marshall, 2004). The positive values of molluscs indicate a relatively high exchange with atmospheric $\mathrm{CO}_{2}$ and/or noticeable loss of depleted $\mathrm{CO}_{2}$ in the DIC pool of the lake by other mechanisms (e.g., high productivity episodes) (Anadón et al., 2008).

\subsubsection{Decapod crustaceans}

Decapod crustaceans were collected from the Upper Travertines and are represented by numerous exceptionally well-preserved specimens of brachyuran crabs (Fig. 9). The degree of travertinisation of the specimens varies widely from almost no calcareous encrusting to an encrustation of several millimetres in thickness. Some of the specimens are completely coated and preserved as three-dimensional outer casts within natural cavities of a white travertine matrix. The preservation of the specimens varies from complete bodies with pereiopods connected to single carapaces or disarticulated bodies with isolated carapaces and displaced pereiopods. The disarticulation of the pereiopods suggests these specimens may present exuviae of juvenile specimens. These observations are congruent with Fraaije et al. (2010) who noted that the crab specimens from the Denizli Basin are "textbook" samples of exuviae of crabs, which moulted hidden in deep crevices. According to Pasini and Garassino (2011), this kind of preservation does not allow observation of the diagnostic characters of the 
carapace and ornamentation. However, the general outline of the subrectangular carapace, the bilobate front with large orbits, the convex anterolateral margins serrated in the anterior part, the posterolateral margins converging posteriorly, the heterochely with the more strongly developed right chela, and the flattened transverse section of the pereiopods support an assignment to the freshwater crab Potamon Savigny, 1816 (Brachyura, Potamidae). Although a specific determination seems difficult, all the studied crabs seem to belong to the same taxon and so form a monotypical assemblage of Potamon. We note that Fraaije et al. (2010) reported some specimens from the same outcrops, and preliminarily identified them as close to the extant Potamon potamios (Olivier, 1804).

Unfortunately, little ecological data are available for potamid crabs (Klaus and Gross, 2009). The extant potamid freshwater crabs seem to show high plasticity concerning abiotic ecological and climatological conditions, and live in variable conditions (Barbaresi et al., 2007). According to Klaus and Gross (2009), the occurrence of Potamon definitely indicates a freshwater environment, which is in agreement with the environmental data of the fossil sites with Potamon species.

The studied fossil potamid crabs are intimately linked to the travertine-forming thermal springs and the active deposit of tufaceous limestones. They probably lived in excavated holes or inhabit natural cavities along or around inland freshwaters. They also used the natural cavities formed inside the travertines as hiding places during the moulting process. As observed in extant potamid crabs, these cavities in which the air humidity remained high enough, might constitute zones of refuge during partial exposure of the lake (Cumberlidge, 2008).

\subsection{Vertebrate palaeontology}

The remains of large mammals from the Upper Travertines from several quarries consist of a number of taxa that have been described by Boulbes et al. (2014). Here, we present an updated list of vertebrate remains that includes the following species:

- monitor lizard (cf. Varanus; Fig. 10(A));

- elephants (Archidiskodon meridionalis meridionalis; Fig. 10(B));

- horses (Equus cf. altidens/E. cf. mygdoniensis and E. cf. apolloniensis; Fig. 10(C, D));

- rhinoceros (Stephanorhinus cf. etruscus; Fig. 10(E));

- small and large-sized deer (Metacervoceros rhenanus, Arvernoceros sp., Cervalces (Libralces) ex gr. minor-gallicus; Fig. 10(F-H)); 
- giraffe (Palaeotragus sp.; Fig. 10(I));

- antelope (Gazella sp.; Fig. 10(J));

- bull (Bovinae gen. indet.; Fig. 10(K)).

The composition of the assemblage is characteristic of Villafranchian European and West Siberian faunas, with some peculiarities. Generically, this association resembles those from the late Villafranchian of southern and eastern Europe and, partly, from eastern Asia, and suggests an age older than 1.2 Ma (Boulbes et al., 2014). The presence of two Equus species, one of them with slender limb bones, is common for the Villafranchian and is the result of low interspecific competition between taxa related to different habitats (Alberdi et al., 1998; Alberdi and Palombo, 2013; Caloi, 2002; Forsten, 1988). Morpho-functional traits in the occurring larger herbivores, most of them thermophilic species occupying a variety of biotopes, allow us to characterise the environmental conditions in the surroundings of the Denizli Basin.

Micro-mammals are represented by two vole molars found within the Upper Conglomerates, illustrated by G. Saraç. The rodent teeth could be assigned to a small Mimomys and a lagurine specimen and are published in this study for the first time (Fig. 10(L, $\mathrm{M})$ ). As the handmade illustration is failing to correctly picture the enamel interruptions on the occlusal side and enamel free areas on the lateral side and information on the external cement or the size are missing, we suggest the re-evaluation of the original molars.

Mimomys ex. gr. reidi-pusillus (Fig. 10(M)). The dentine tracts are possibly interrupted on both lateral and lingual sides, and having in mind that the average occlusal length of lower $\mathrm{m} 3$ in this group is ca. $1.5-1.6 \mathrm{~mm}$, the dentine tracts are higher than 1.3$1.4 \mathrm{~mm}$. Values like this are characteristic for the latest Gelasian to Calabrian forms. In Western and Central Europe the reliable records of $M$. pusillus are restricted to the Calabrian (compare to Rodent zone Mimomys savini + Mimomys pusillus of Fejfar et al. (1998) with estimated duration from 1.85 to 0.8 Ma). In mesic forest-steppe faunas of Eastern Europe, however, Mimomys pusillus is reliably traced into early middle Pleistocene (Cromerian) faunas (Agajanian, 2009). The geographic position of the Denizli Basin suggests a Western European faunal pattern and restricts the upper time limit of $M$. ex. gr. reidi-pusillus to the Calabrian.

The morphology of the well preserved lagurine $\mathrm{m} 1$ can be assigned to Lagurus transiens and therefore indicates an early middle Pleistocene (Cromerian) age (Fig. 10(L)). However, the close comparison with the material of the early Pleistocene fauna of Dursunlu (Ünay, 1998) suggests an attribution of this molar to an advanced population of Lagurodon 
arankae, and a late early Pleistocene (Calabrian) age. Thus, both fossils likely indicate a time of deposition older than 0.8 Ma.

The presence of elephants, giraffes, deer, and different voles attest to the overall mixed character of the environment, ranging from abundant tall, shrubby, arboreous and near-water vegetation to a savannah-like landscape. The presence of larger deer further hints at the development of lakeside thickets. The slender Equus species that appears together with gazelles and Etruscan rhinoceros is indicative of an open and widespread landscape with sparse occurring shrubs. Overall, we hypothesize that the basin was a watering place with ample vegetation that attracted the herein described herbivorous animals.

\subsection{Palaeobotany}

Several well preserved leaf imprints found in the Upper Travertines were examined. A few specimens exhibit a complete preservation of the leaf casts, sometimes including the apices and bases. The leaves are preserved in their three dimensional shapes (folded as on the tree or fresh litter), thus indicating only a short maceration in water. The flora recovered is fairly diverse and composed of several trees that are present in warm Mediterranean region today. The limb margin of most specimens is preserved and visible, allowing identification of the species. The identified most common taxa include: Quercus sp. (cf. Q. cerris L.), Celtis australis L., Ziziphus nummularia (Burm. f.) Wight et Arn. and/or Ziziphus ziziphus (L.) Meikle, Rhamnus cathartica L., Ficus carica L. and Ficus sp., Alnus sp. and Ulmus sp., and unidentified Rosaceae. This assemblage clearly evokes an open woodland (Quercus, Celtis, Alnus and Ulmus) with shrubs (Ziziphus, Rhamnus and Ficus) of a warm Mediterranean environment as found today in South European and North African regions. We can notice that these taxa are also today present in the area and in the southern part of Turkey in general (Semiz and Celik, 2005). The rarity of herbaceous plants (only a probable Primula sp.) may be a matter of preservation.

\section{Discussion}

Our integrated analytical results demonstrate that the Pleistocene continental deposits of the Denizli Basin show a wide range of depositional palaeoenvironments. The Kocabaş site is today located at a major transition from semi-humid environments of the SW Anatolian mountain ranges to the dry Anatolian interior high plateau. It is also located at the crossroads of a major faunal and human migration route (Kappelman et al., 2008; Vialet et al., 2018; Krijgsman et al., 2019). 
The stratigraphic succession shows lacustrine and terrestrial carbonate accumulations alternating with fluvial-lacustrine siliciclastic deposits. The lowermost unit (Lower Travertine) corresponds to the massive, light beige limestone interpreted to be of subaqueous nature, yielding no fossil remains. The micritic limestone can be associated to a shallow lake depositional environment. The overlaying siliciclastic deposits (Lower Conglomerates) accumulated within fluvial facies initiated with a high-energy, pebble-carrying environment and ends with low-energy conditions depositing a fine layer of chalky limestone. In between, the coarse sands are most likely the result of erosional currents. The Lower Conglomerates are covered by lacustrine and terrestrial limestone accumulations, which correspond to the Upper Travertine unit. The lacustrine carbonates pass upward into a thin layer of lacustrine marls that are overlaid by porous travertine. Travertine is considered a freshwater limestone that forms when hot ground water, rich in calcium and bicarbonate, emerges at springs (Guo and Riding, 1998). Outgassing of $\mathrm{CO}_{2}$ causes rapid travertine precipitation. The deposits precipitated in different depositional environments show a variation in colour, bedding, porosity, texture and composition, which frequently changes in both lateral and vertical directions within short distances. This variability may be the result of the underlying topography, spring position and chemical composition of travertine-depositing waters or organic activities (Altunel, 1994). Different travertine accumulations in the Denizli Basin were separated into lithofacies and later tied to different depositional environments by Altunel (1996). The inhomogeneous and porous travertine that follows the marly deposits is interpreted as a limestone tuff linked to a cascade/waterfall setting and a prograding slope environment and reed facies described by Guo and Riding (1998). A similar setting is observed today in the Pamukkale site. Guo and Riding (1998) described the facies as characterized by asymmetrically developing mounds, deposited over a significant topographic relief, associated with a slope environment at the edge of a basin. Since some of the mammal findings are found articulated, indicating only minor transport, we assume that the animals died on the travertine slope at the lake margin that subsequently was covered by carbonateladen waters, precipitating travertine that migrated into the lake. The accumulated mammal remains, abundant potamid crabs and findings of leaf imprints indicate the presence of a marshy environment, providing ample vegetation and a freshwater source that attracted both the early hominins and their potential prey species. The hominin calvaria-bearing travertine unit was dated between 1.6 and 1.2 Ma (Lebatard et al., 2014), corresponding to the late early Pleistocene when the climate was not yet very cold due to shortened climatic cycles (40 k.y.), marked by glaciations during short periods (Lisiecki and Raymo, 2005). Pollen data delivered 
by the lacustrine record of the Acıgöl Basin, an adjacent basin with a sedimentary record spanning over the same time frame as the studied succession, indicate a fairly open landscape (arboreal pollen $<50 \%$ of the pollen sum) with steppe formations dominated by Artemisia, Poaceae and Chenopodiaceae during glacial phases, and a mosaic landscape with a diversified Mediterranean-type forest with gymnosperms (dominant Pinus, followed by Abies, Cedrus, Picea and Cupressaceae), broadleaved and evergreen Quercus forest and steppe grasslands during interglacials (Andrieu-Ponel et al., 2016). Coprophilous fungi spores testify to the presence of herds of large mammals. Palaeoflora obtained from palynology and macrofossil studies converge on the same Mediterranean environment with several facies of open (savannah to scrub) woodlands.

Homo erectus is among the first hominins to expand into a wide range of environments outside of Africa into more temperate climates of Eurasia (Messager et al., 2009; Anton et al., 2016). The factors that are responsible for such expansion were debated by Prat (2018) while most of the authors consider that it was most likely driven by climatic and environmental changes and has been related to technological, energetic and foraging shifts tied to a high developmental plasticity (DeMenocal and Bloemendal, 1995; Potts, 1998; Zeitoun, 2000; Holmes, 2007; Messager et al., 2009; Anton et al., 2016). The ability to adjust to environmental conditions is considered a key factor for Homo sapiens to inhabit a variety of habitats, but it may have also been present in H. erectus (Anton et al., 2016; Prat, 2018). Equipped with the capability to adapt and endure periods of climatic changes, Homo erectus also lived in the mixed environments of the Caucasus region (Messager et al., 2009). The authors concluded the presence of an arid and open to grassland and forest-steppe ecosystems, based on findings at the well-known Dmanisi site. Moreover, they suggested that the presence of a mixed ecosystem most probably played an important role in maintaining the ecological niches for the large mammal species. The assumptions made in Dmanisi and the Acıgöl Basin are in agreement with the prevailing setting studied inside the Denizli Basin.

The vertical succession of the Faber quarry terminates in the siliciclastic sediments of the Upper Conglomerates, interpreted to have been deposited within a shore-face setting and a shallow lake environment. The micropalaeontological evidence suggests the presence of an anomalohaline lake setting, intercalated by conglomeratic intervals indicating a shift into a higher energy environment. Due to the progressive onlap of this unit onto the previous travertine interval, we further assume that these deposits result from the lateral migration of channels related to the growth of the levee, resulting in autocyclic sedimentation. According to Beerbower (1964), autocylicity is defined as the shifting of locations of deposition as well 
as variation in grain size because of factors intrinsic to the sedimentary system. The mixture of freshwater and oligohaline to mesohaline ostracods derived from the fine grained intervals, which are the result of a lower energy deposition, suggests a shallow water environment. The mollusc assemblage that forms a layer at the base of one of the conglomerate intervals most likely emerged from two different origins, namely a spring environment and an oligohaline lake. The uppermost unit of the succession is likely to represent the northern shoreline of the southeastern extension of the Denizli palaeolake (Fig. 11), which was subject to lacustrine transgressions that were triggered by tectonic and climatic changes.

Being located in one of the most active extensional tectonic regions in the World, these travertine and fluvial deposits provide an important insight into the Denizli Basin evolution during the early Pleistocene uplift. The Faber quarry is located in the eastern part of the basin, whose floor gently slopes towards the north and northeast. There is no sign of potential basin thresholds apparent in the vicinity of the Kocabaş site, suggesting that the Denizli Basin was covered by a single, anomalohaline lake during the late early Pleistocene. Additional data are needed to clarify the possible relationships to the long-lived lake that existed during the late Pliocene-early Pleistocene near the town of Tosunlar located NE of Denizli (Alçiçek et al., 2015). The modern graben system in the western Anatolian extensional province originated most probably around the middle Pleistocene (Koçyiğit, 2005), implying that the long-lived lake must have ceased to exist only after Homo erectus settled at its margins.

\section{Conclusions}

The early Pleistocene palaeoenvironment evidenced in the Kocabaş succession, characterized by alternating travertine and fluvial-lacustrine carbonate deposits, can be associated to the presence of: (i) travertine springs and streams, (ii) high energy lacustrine sedimentation linked to lateral migration of channels, and (iii) fine-grained sediment accumulation inside an anomalohaline lake environment. The travertine springs and streams presumably presented a valuable freshwater source to Homo erectus and other animals. The freshwater source further attracted large herbivores well represented in the palaeontological record, providing important information on the palaeoenvironment that consisted of a mixed landscape (shrubby, arboreous and near-water vegetation to a savannah-like landscape) in a temperate climate. The high biodiversity evidenced in such area, including the fauna and flora, might be considered as potential resources for Homo erectus. 


\section{Acknowledgements}

This study would not have been possible without the help and access throughout the year by the management of the Faber Quarry. In particular, we thank Haydar Alptekin, Koray Ateş and Uğur Korkmaz, and the director Nejdet Karakuyu for their support. We further thank John Kappelman (University of Texas) for his constructive and helpful advice. The study was supported by international bilateral cooperation project between the Scientific and Technological Research Council of Turkey and the French Scientific Research National Center (CNRS; PICS program “First Human in Turkey” 2016-2018), research grant no. TUBITAK-CNRS 110Y335 and the European Union's Horizon 2020 research and innovation Program PRIDE ("Pontocaspian Rise and Demise”) under the Marie Sklodowska-Curie grant agreement No. 642973. M.C.A. is grateful to the Turkish Academy of Sciences (TUBA) for a GEBIP (Young Scientist Award) grant. T.A.N. was supported by an Alexander-vonHumboldt fellowship.

\section{References}

Agajanian, A.K., 2009. [Pliocene-Pleistocene small mammals of the Russian Plain]. Nauka Press, Moscow, 676 p. (In Russian)

Akay, E., Uysal, S., Poisson, A., Cravatte, J., Müller, C., 1985. Stratigraphy of the Antalya Neogene basin. Bulletin of the Geological Society Turkey 28, 105-119.

Alberdi, M.T., Palombo, M.R., 2013. The late Early to early Middle Pleistocene stenonoid horses from Italy. Quaternary International 288, 25-44.

Alberdi, M.T., Ortiz Jauregizar, E., Prado, J.L., 1998. A Quantitative review of European stenonid horses. Journal of Paleontology 72, 371-387.

Albrecht, C., von Rintelen, T., Sereda, S., Riedel, F., 2014. Evolution of ancient lake bivalves: the Lymnocardiinae (Cardiidae) of the Caspian Sea. Hydrobiologia 739, 8594.

Alçiçek, H., Bülbül, A., Yavuzer, İ., Alçiçek, M. C., 2019a. Origin and evolution of the thermal waters from the Pamukkale Geothermal Field (Denizli Basin, SW Anatolia, Turkey): Insights from hydrogeochemistry and geothermometry. Journal of Volcanology and Geothermal Research 372, 48-70.

Alçiçek, H., Bülbül, A., Yavuzer, İ., Alçiçek, M.C., 2019b. Hydrogeochemical and isotopic assessment and geothermometry applications of the Karahayit Geothermal Field (Denizli Basin, SW Anatolia, Turkey). Hydrogeology Journal 27, 1791-1816. 
Alçiçek, H., Bülbül, A., Capezzuoli, E., Brogi, A., Liotta, D., Meccheri, M., Riggueri, G., Yavuzer, İ., Alçiçek, M.C., 2017. Origin, evolution and geothermometry of thermal waters in the Gölemezli Geothermal Field, Denizli Basin (SW Turkey). Journal of Volcanology and Geothermal Research 349, 1-30.

Alçiçek, H., Wesselingh, F. P., Alçiçek, M. C., Jiménez-Moreno, G., Feijen, F. J., van den Hoek Ostende, L. W., Mayda, S., Tesakov, A. S., 2017. A multiproxy study of the early Pleistocene palaeoenvironmental and palaeoclimatic conditions of an anastomosed fluvial sequence from the Çameli Basin (SW Anatolia, Turkey). Palaeogeography, Palaeoclimatology, Palaeoecology 467, 232-252.

Alçiçek, H., Bülbül, A., Alçiçek, M.C., 2016. Hydrogeochemistry of the thermal waters from the Yenice Geothermal Field (Denizli Basin, SW Turkey). Journal of Volcanology and Geothermal Research 309, 118-138.

Alçiçek, H., Wesselingh, F., Alçiçek, M.C., 2015. Paleoenvironmental evolution of the late Pliocene-early Pleistocene fluvio-deltaic sequence of the Denizli Basin (SW Turkey). Palaeogeography, Palaeoclimatology, Palaeoecology 437, 98-116. Alçiçek, M.C., 2014. Historique de la découverte et des recherches sur la calotte crânienne d’Homo erectus archaïque de Kocabaş, Bassin de Denizli, Anatolie, Turquie. L’Anthropologie 118, 8-10.

Alçiçek, H., Alçiçek, M.C., 2014. Contexte géographique et géologique du site de Kocabaş, Bassin de Denizli, Anatolie, Turquie. L’Anthropologie 118, 11-15.

Alçiçek, H., 2010. Stratigraphic correlation of the Neogene basins in southwestern Anatolia: regional palaeogeographical, palaeoclimatic and tectonic implications. Palaeogeography, Palaeoclimatology, Palaeoecology 291, 297-318.

Alçiçek, H., Varol, B., Özkul, M., 2007. Sedimentary facies, depositional environments and palaeogeographic evolution of the Neogene Denizli Basin of SW Anatolia, Turkey. Sedimentary Geology 202, 596-637.

Altunel, E., 1994. Active tectonics and the evolution of Quaternary travertines at Pamukkale, Western Turkey. Ph.D. Thesis, University of Bristol, 236 p. (unpubl.).

Altunel, E., 1996. Pamukkale travertenlerinin morfolojik özellikleri, yaşları ve neotektonik önemler. Maden Tetkik Arama Dergisi 118, 47-64.

Altunel, E., Hancock, P.L., 1993a. Active fissuring and faulting in Quaternary travertines at Pamukkale, western Turkey. Zeitschrift für Geomorphologie NF, 285-302.

Altunel, E., Hancock, P.L., 1993b. Morphology and structural setting of Quaternary travertines at Pamukkale, Turkey. Geological Journal 28, 335-346. 
Altunel, E., Hancock, P.L., 1993c. Pamukkale travertenleri kaç yaşında. Bilim ve Teknik Dergisi 26/308, 496-497.

Altunel, E., Hancock, P.L., 1996. Structural attributes of travertine-filled extensional fissures in the Pamukkale Plateau, Western Turkey. International Geology Review 38, 768-777.

Altunel, E., Karabacak, V., 2005. Determination of horizontal extension from fissure-ridge travertines: a case study from the Denizli Basin, southwestern Turkey. Geodinamica Acta 18, 333-342.

Anadón, P., Utrilla, R., Vázquesz, A., Martín-Rubio, RodriquezLázaro, J., Robles, F., 2008. Paleoenvironmental evolution of the Pliocene Villarroya Lake, northern Spain, from stable isotopes and trace-element geochemistry of ostracods and molluscs. Journal of Paleolimnology 39, 399-419.

Andrieu-Ponel, V., Demory, F., Perrin, M., Alçiçek, M.C., Lebatard, A.E., Nomade, S., Djamali, M., Rochette, P., Helvaci, C., 2016. The long climatic sequence of Acigol Lake, NW. Turkey: chronological and palynological results. Réunion des Sciences de la Terre (RST), Caen, 24-28/10/2016.

Ansell, S.W., Stenøien, H. K., Grundmann, M., Russell, S. J., Koch, M. A., Schneider, H., Vogel, J. C., 2011. The importance of Anatolian mountains as the cradle of global diversity in Arabis alpina, a key arctic-alpine species. Annals of botany 108, 241-252.

Anton, S. C., Taboada, H. G., Middleton, E. R., Rainwater, C. W., Taylor, A. B., Turner, T. R., Turnquist, J.E, Weinstein, K.J., Williams, S. A., 2016. Morphological variation in Homo erectus and the origins of developmental plasticity. Philosophical Transactions of the Royal Society Biological Sciences 371, 20150236.

Arconada, B., Ramos, M.-A., 2006. Revision of the Genus Islamia Radoman, 1973

(Gastropoda, Caenogastropoda, Hydrobiidae) on the Iberian Peninsula and Description of Two New Genera and Three New Species. Malacologia 48, 77-132.

Atalay, İ., 1996. Palaeosols as indicators of the climatic changes during Quaternary period in S. Anatolia. Journal of Arid Environments 32, 23-35.

Barbaresi, S., Cannicci, S., Vannini, M., Fratini, S., 2007. Environmental correlates of two macro-decapods distribution in Central Italy: multi-dimensional ecological knowledge as a tool for conservation of endangered species. Biological Conservation 136, 431441.

Beerbower, J.R., 1964. Cyclothems and cyclic depositional mechanisms in alluvial plain sedimentation. Kansas Geological Survey Bulletin 169, 31-32. 
Bodon, M., Manganelli, G., Giusti, F., 2001. A survey of the European valvatiform hydrobiid genera, with special reference to Hauffenia Pollonera, 1898 (Gastropoda: Hydrobiidae). Malacologia 43, 103-215.

Boomer, I., Frenzel, P., Feike, M., 2017. Salinity-driven size variability in Cyprideis torosa (Ostracoda, Crustacea). Journal of Micropalaeontology 36, 63-69.

Boulbes, N., Mayda, S., Titov, V.V., Alçiçek, M.C., 2014. Les grands mammifères pléistocènes des travertins du Bassin de Denizli, Sud-ouest de l’Anatolie, Turquie. L’Anthropologie 118, 44-73.

Bozkurt, E., 2001. Neotectonic of Turkey - a synthesis. Geodinamica Acta 14, 3-30.

Brogi, A., Capezzuoli, E., Alçiçek, M.C., Gandin, A., 2014. Evolution of a fault-controlled travertine fissure-ridge in the western Anatolia extensional province: the Çukurbag fissure-ridge (Pamukkale, Turkey). Journal of the Geological Society 171, 425-441.

Brogi, A., Alçiçek, M.C., Yalçıner, C.C., Capezzuoli, E., Liotta, D., Meccheri, M., Rimondi, V., Ruggieri, G., Gandin, A., Boschi, C., Büyüksaraç, A., Alçiçek, H., Bülbül, A., Baykara, M.O., Shen, C.C., 2016. Hydrothermal fluids circulation and travertine deposition in an active tectonic setting: insights from the Kamara geothermal area (western Anatolia, Turkey). Tectonophysics 680, 211-232.

Bukowski, G., 1930. Bemerkungen über die Binnenablagerungen in der Umgebung des Buldur Giöl in Kleinasien. Annales Societatis Geologorum Poloniae 6, 73-90.

Caloi, L., 2002. The two equids of the middle Pleistocene of the site Venosa-Loreta (Southern Italy): functional morphology of the cranial remains. Geologica Romana 36, 275-287. Çakır, Z., 1999. Along - Strike Discontinutiy of Active Normal Faults and Its Influence on Queternary TravertineDeposition: Examples from Western Turkey. Turkish Journal of Earth Sciences 8, 67-80.

Capezzuoli, E., Ruggieri, G., Rimondi, V., Brogi, A., Liotta, D., Alçiçek, M. C., Alçiçek, H., Bülbül, A., Gandin, A., Meccheri, M., Shen, C.C., Baykara, M.O., 2018. Calcite veining and feeding conduits in a hydrothermal system: Insights from a natural section across the Pleistocene Gölemezli travertine depositional system (western Anatolia, Turkey). Sedimentary Geology 364, 180-203.

Carbonell, E., Bermúdez de Castro, J.M., Parés, J.M., Pérez-González, A., Cuenca-Bescós, G., Ollé, A., Mosquera, M., Huguet, R., van der Made, J., Rosas, A., Sala, R., Vallverdú, J., García, N., Granger, D.E., Martinón-Torres, M., Rodríguez, X.P., Stock, G.M., Vergès, J.M., Allué, E., Burjachs, F., Cáceres, I., Canals, A., Benito, A., Diez, C., 
Lozano, M., Mateos, A., Navazo, M., Rodríguez, J., Rosell, J., Arsuaga, J.L., 2008. The first hominin of Europe. Nature 452, 465-469.

Cita, M. B., 1982. The Messinian salinity crisis in the Mediterranean: a review. Alpine -MYladBterfanean Geodynamics

Cumberlidge, N., 2008. Potamon ibericum. The IUCN Red List of Threatened Species 2008: e.T134681A3997379.

Cummings, K.S., Graf, D.L., 2015. Class Bivalvia. In: Thorp, J.H., Rogers, D.C. (Eds), Thorp and Covich's Freshwater Invertebrates (Fourth Edition). Academic Press, Elsevier, Boston, pp. 423-506.

Davis, P. H., 1965. Flora of Turkey and the East Aegean Islands. Edinburgh University Press.

De Filippis, L., Faccenna, C., Billi, A., Anzalone, E., Brilli, M., Soligo, M. Tuccimei, P., 2013. Plateau versus fissure ridge travertines from Quaternary geothermal springs of Italy and Turkey: Interactions and feedbacks between fluid discharge, paleoclimate and tectonics. Earth-Science Reviews 123, 35-52.

DeMenocal, P.B.D., Bloemendal, J., 1995. Plio-Pleistocene climatic variability in subtropical Africa and the paleoenvironment of hominid evolution: a combined data-model approach. Paleoclimate and evolution with emphasis on human origins. Yale University Press, New Haven, pp. 262-288.

Erten, H., Sen, S., Özkul, M., 2005. Pleistocene mammals from travertine deposits of the Denizli basin (SW Turkey). Annales de Paléontologie 91, 267-278.

Falguères, C., 2003. ESR dating and the human evolution: contribution to the chronology of the earliest humans in Europe. Quaternary Science Reviews 22, 1345-1351.

Faranda, C., Gliozzi, E., Ligios, S., 2007. Late Miocene brackish Loxoconchidae (Crustacea, Ostracoda) from Italy. Geobios 40, 303-324.

Fejfar, O., Heinrich, W.-D., Lindsay, E.H., 1998. Updating the Neogene rodent biochronology in Europe. Mededelingen Nederlands Instituut voor Toegepaste Geowetenschappen TNO 60, 533-554.

Fraaije, R.H.B., van Bakel, B.W.M., Jagt, J.W.M., 2010. Exceptional preservation of Pleistocene freshwater crabs from southwest Turkey. 4th Symposium on Mesozoic and Cenozoic Decapod Crustaceans, Eichstatt, p. 8.

Forsten, A., 1988. Middle Pleistocene replacement of stenonid horses by caballoid horses. Ecological implications. Palaeogeography, Palaeoclimatology, Palaeoecology 65, 2333. 
Glöer, P., 2002. Die Tierwelt Deutschlands, 73. Teil: Die Süßwassergastropoden Nord- und Mitteleuropas. Bestimmungsschlüssel, Lebensweise, Verbreitung. ConchBooks, Hackenheim.

Glöer, P., Pešić, V., 2015. The morphological plasticity of Theodoxus fluviatilis (Linnaeus, 1758) (Mollusca: Gastropoda: Neritidae). Ecologica Montenegrina 2, 88-92.

Glöer, P., Rähle, W., 2009. Gyraulus pamphylicus n. sp. - a new species from Turkey (Mollusca: Gastropoda: Planorbidae). Mollusca 27, 57-60.

Guo, L., Riding, R., 1998. Hot

Rapolano Terme, Italy. Sedimentology 45, 163-180.

Güçlü, S.S., 2003. Kırkgöz kaynağı (Antalya)'nda yaşayan Aphanius mento (Heckel in: Russegger, 1843)'nun beslenme, büyüme ve üreme özelliklerinin araştırılması. Süleyman Demirel Üniversitesi Fen Bilimleri Enstitüsü, Isparta.

Hancock, P. L., Chalmers, R. M. L., Altunel, E., Çakır, Z., 1999. Travitonics: using travertines in active fault studies. Journal of Structural Geology 21, 903-916.

Holmes, K.M., 2007. Using Pliocene palaeoclimatic data to postulate dispersal pathways of early hominins. Palaeogeography, Palaeoclimatology, Palaeoecology 248, 96-108.

Kappelman, J., Alçiçek, M.C., Kazancı, N., Schultz, M., Özkul, M., Şen, Ş., 2008. First Homo erectus from Turkey and implications for migrations into temperate Eurasia. American Journal of Physical Anthropology 135, 110-116.

Kaymakçı, N., 2006. Kinematic development and paleostress analysis of the Denizli Basin (Western Turkish): implications of spatial variation of relative paleostress magnitudes and orientations. Journal of Asian Earth Sciences 27, 207-222.

Kebapçi, Ü., Bahadir Koca, S., Yıldırım, M.Z., 2012. Revision of Graecoanatolica (Gastropoda: Hydrobiidae) species in Turkey. Turkish Journal of Zoology 36, 399-411. Kebapçi, Ü., Yıldırım, M.Z., 2010. Freshwater snails fauna of lakes region (Göller bölgesi), Turkey. Muzeul Olteniei Craiova. Oltenia. Studii şi comunicări. Ştiinţele Naturii 26, 7583.

Khatib, S., Rochette, P., Alçiçek, M. C., Lebatard, A. E., Saos, T., 2014. Stratigraphic, sedimentological and paleomagnetic study of the Kocabas travertines, Denizli Basin, Anatolia. L’Anthropologie 118, 16-33.

Kilenyi, T.I., 1972. Transient and balanced genetic polymorphism as an explanation of variable noding in the ostracode Cyprideis torosa. Micropaleontology 18, 47-63. Kijashko, P.V., 2013. Glava 5. Mollyuski kaspiyskogo morya. In: Bogutskaya, N.G., Kijashko, P.V., Naseka, A.M., Orlova, M.I. (Eds), Opredelitel' ryb i bespozvonochnykh 
Kaspiyskogo morya. T. 1. Ryby i mollyuski. KMK Scientific Press Ltd., St. Petersburg, Moscow, pp. 298-392.

Kim, S.T., Mucci, A., Taylor, B.E., 2007. Phosphoric acid fractionation factors for calcite and aragonite between 25 and 75 C: revisited. Chemical Geology 246, 135-146.

Kingston, J.D., 2007. Shifting adaptive landscapes: progress and challenges in reconstructing early hominid environments. American Journal of Physical Anthropology: The Official Publication of the American Association of Physical Anthropologists 134, 20-58.

Klaus, S., Gross, M., 2009. Synopsis of the fossil freshwater crabs of Europe (Brachyura: Potamoidea: Potamidae). Neues Jahrbuch für Geologie und Paläontologie, Abhandlungen 256, 39-59.

Koçyiğit, A., 2005. The Denizli graben-horst system and the eastern limit of the western Anatolian continental extension: basin fill, structure, deformational mode, throw amount and episodic evolutionary history, SW Turkey. Geodinamica Acta 18, 167-208. Krijgsman, W., Tesakov, A., Yanina, T., Lazarev, S., Danukalova, G., Van Baak, G.C.G., Agustí, J., Alçiçek, M.C., Aliyeva, E., Bista, D., Bruch, A., Büyükmeriç, Y., Bukhsianidze, M., Flecker, R., Frolov, P., Hoyle, T.M., Jorissen, E.L., Kirscher, U., Koriche, S.A., Oms, O., Rausch, L., Singarayer, J., Stoica, M., Van de Velde, S.V., Titov, V.V., Wesselingh, F.P., 2019. Quaternary time scales for the Pontocaspian domain: interbasinal connectivity and faunal evolution. Earth Science Reviews 188, 140.

Krstić, N., 1985. Ostracoden im Pannonien der Umgebung von Belgrad. In: Papp, A., Jámbor, Á., Steininger, F.F. (Eds), Chronostratigraphie und Neostratotypen. Miozän der Zentralen Paratethys, Bd. VII, M6. Pannonien (Slavonien und Serbien). Verlag der Ungarischen Akademie der Wissenschaften, Budapest, pp. 103-143.

Konak, N., 2002. Geological map of Turkey in 1/500.000 scale: İzmir sheet. Publication of Mineral Research and Exploration Directorate of Turkey (MTA), Ankara.

Konak, N., Şenel, M., 2002. Geological map of Turkey in 1/500.000 scale: Denizli sheet. Publication of Mineral Research and Exploration Directorate of Turkey (MTA), Ankara.

Lebatard, A.-E., Alçiçek, M.C., Rochette, P., Khatib, S., Vialet, A., Boulbes, N., Bourlès, D.L., Demory, F., Guipert, G., Mayda, S., Titov, V.V., Vidal, L., de Lumley, H., 2014a. Dating the Homo erectus bearing travertine from Kocabaş (Denizli, Turkey) at least 1.1 Ma. Earth and Planetary Science Letters 390, 8-18. 
Lebatard, A.-E., Bourlès, D.L., Alçiçek, M.C., 2014b. Datation des travertins de Kocabaş par la méthode des nucléides cosmogéniques ${ }^{26} \mathrm{Al} /{ }^{10} \mathrm{Be}$. L’Anthropologie 118, 34-43.

Leng, M.J., Marshall, J.D., 2004. Palaeoclimate interpretation of stable isotope data from lake sediments. Quaternary Science Reviews 23, 811-831.

Lips, A.L.W., Cassard, D., Sözbilir, H., Y1lmaz, H., 2001. Multistage exhumation of the Menderes Massif, western Anatolia (Turkey). International Journal of Earth Sciences 89, 781-792.

Lisiecki, L.E., Raymo, M.E., 2005. A Pliocene-Pleistocene stack of 57 globally distributed benthic $\delta 180$ records. Paleoceanography, 20, PA1003.

Mesci, L. B., Tatar, O., Piper J. D. A., Gürsoy, H., Altunel, E., Crowley, S., 2013. The efficacy of travertines as a palaeoenvironmental indicator: palaeomagnetic study of neotectonic examples from Denizli, Turkey. Turkish Journal of Earth Sciences 22, 191203.

Meisch, C., 2000. Freshwater ostracoda of Western and Central Europe. Spektrum Heidelberg.

Messager, E., Lordkipanidze, D., Kvavadze, E., Ferring, C. R., Voinchet, P., 2010.

Palaeoenvironmental reconstruction of Dmanisi site (Georgia) based on palaeobotanical data. Quaternary International 223, 20-27.

Olivier, G.A., 1801. Voyage dans l'Empire Othoman, l'Égypte et la Perse, fait par ordre du gouvernement, pendant les six premières années de la République. Tome premier. Agasse, Paris.

Oms, O., Parés, J. M., Martínez-Navarro, B., Agustí, J., Toro, I., Martínez-Fernández, G., Turq, A., 2000. Early human occupation of Western Europe: paleomagnetic dates for two paleolithic sites in Spain. Proceedings of the National Academy of Sciences of the USA 97, 10666-10670.

Orain, R., Lebreton, V., Russo Ermolli, E., Sémah, A. M., Nomade, S., Shao, Q., Peretto, C., 2013. Hominin responses to environmental changes during the Middle Pleistocene in central and southern Italy. Climate of the Past 9, 687-697.

Orlova, M.I., Muirhead, J.R., Antonov, P.I., Shcherbina, G.Kh., Starobogatov, Y.I., Biochino, G.I., Therriault, T.W., MacIsaac, H.J., 2005. Range expansion of quagga mussels Dreissena rostriformis bugensis in the Volga River and Caspian Sea basin. Aquatic Ecology 38, 561-573.

Pasini, G., Garassino, A., 2011. Unusual scaled preservation samples on freshwater decapods (Crustacea, Decapoda) from the Pleistocene (Late Cenozoic) of Turkey and Kazakistan. 
Atti della Società italiana di Scienze naturali e del Museo di Storia naturale in Milano 152, 13-18.

Popa, L., Popa, O., Iorgu, E., Kelemen, B., Murariu, D., 2012. Molecular insights into the taxonomy of Hypanis (Bivalvia, Cardiidae, Lymnocardiinae) in the Black Sea lagoons. Helgoland Marine Research 66, 153-158.

Potts, R., 1998. Environmental hypotheses of hominin evolution. American Journal of Physical Anthropology 107, 93-136.

Prat, S., 2016. First hominin settlements out of Africa. Tempo and dispersal mode: Review and perspectives. Comptes Rendus Palevol 17, 6-16.

Radea, C., Parmakelis, A., Vardinoyannis, S., Vardinoyannis, K., 2017. A new Islamia species (Gastropoda: Hydrobiidae) from Cyprus. Folia Malacologica 25, 231-236.

Radoman, P., 1973. New classification of fresh and brakish water Prosobranchia from the Balkans and Asia Minor. Prirodnjacki Muzej u Beogradu, Posebna Izdanja 32, 3-30.

Radoman, P., 1983. Hydrobioidea, a superfamily of Prosobranchia (Gastropoda). I. Systematics. Serbian Academy of Sciences and Arts, Belgrade.

Roberts, N., Wright, H.E. Jr, 1993. Vegetational lake-level, and climate history of the Near East and southwest Asia. Global Climates Since the Last Glacial Maximum, pp. 194220.

Schütt, H., 1964. Die Molluskenfauna eines reliktären Quellsees der südlichen Türkei. Archiv für Molluskenkunde 93, 173-180.

Schütt, H., 1965. Zur Systematik und Ökologie türkischer Süßwasserprosobranchier. Zoologische mededelingen 41, 43-72.

Schütt, H., 1991. Fossile Mollusken dreier anatolischer Ovas. Archiv für Molluskenkunde $120,131-147$.

Schütt, H., Yıldırım, Z.A., 1999. A new freshwater snail from the Beyşehir Lake in Southwest Anatolia (Gastropoda: Prosobranchia: Hydrobioidea). Malakologische Abhandlungen 19, 243-246.

Şengör, A.M.C., Yilmaz, Y., 1981. Tethyan evolution of Turkey: a plate tectonic approach. Tectonophysics 75, 181-241.

Sémah, F., Saleki, H., Falguères, C., Féraud, G., Djubiantono, T., 2000. Did early man reach Java during the Late Pliocene? Journal of Archaeological Science 27, 763-769.

Schweizer, G., 1975. Untersuchungen zur Physiogeographie von Ostanatolien und Nordwestiran: geomorphologische, klima-und hydrogeographische Studien in Vansee- 
und Rezaiyehsee-Gebiet (Vol. 9). Selbstverlag des Geographischen Instituts der Universität Tübingen.

Semiz, G., Celik, A., 2005. Flora planine Aydogdu (Denizli/Turska). Natura Croatica: Periodicum Musei Historiae Naturalis Croatici 14, 185-212.

Şimşek, Ş., 1984. Denizli-Kızıldere-Tekkehamam-Tosunlar-Buldan-Yenice alanının jeolojisi ve jeotermal enerji olanakları. Mineral Resources and Exploration Directory of Turkey (MTA) Scientific Report 7846, 85 p. (In Turkish)

Şimşek, Ş., Günay, G., Elhatip, H., Ekmekçi, M., 2000. Environmental protection of geothermal waters and travertines at Pamukkale, Turkey. Geothermics 22, 557-572.

Sözbilir, H., 2005. Oligo-Miocene extension in the Lycian orogen: evidence from the Lycian mollase basin, SW Turkey. Geodinamica Acta 18, 255-282.

Stoica, M., Lazăr, I., Krijgsman, W., Vasiliev, I., Jipa, D., Floroiu, A., 2013.

Paleoenvironmental evolution of the East Carpathian foredeep during the late Mioceneearly Pliocene (Dacian Basin; Romania). Global and Planetary Change 103, 135-148.

Sun, S., 1990. Denizli-Uşak Arasının Jeolojisi ve Linyit Olanakları. Mineral Resources and Exploration Directory of Turkey (MTA) Scientific Report 9985, 92 p. (in Turkish)

Swisher, C.C., Curtis, G.H., Jacob, T., Getty, A.G., Suprijo, A., 1994. Age of the earliest known hominids in Java, Indonesia. Science 263, 1118-1121.

Ten Veen, J.T., Boulton, S.J., Alçiçek, M.C., 2009. From palaeotectonics to neotectonics in the Neotethys realm: The importance of kinematic decoupling and inherited structural grain in SW Anatolia (Turkey). Tectonophysics 473, 261-281.

Therriault, T.W., Docker, M.F., Orlova, M.I., Heath, D.D., MacIsaac, H.J., 2004. Molecular resolution of the family Dreissenidae (Mollusca: Bivalvia) with emphasis on PontoCaspian species, including first report of Mytilopsis leucophaeata in the Black Sea basin. Molecular Phylogenetics and Evolution 30, 479-489.

Ünay, E., 1998. Allophaiomys from Turkey. Paludicola 2, 106-109.

Vesper, B., 1972. Zum problem der Buckelbildung bei Cyprideis torosa (Jones, 1850)(Crustacea, Ostracoda, Cytheridae). Mitteilungen aus dem Hamburgischen Zoologischen Museum und Institut 68, 94.

Vialet, A., Guipert, G., Alçiçek, M.C., 2012. Homo erectus found still further west: Reconstruction of the Kocabaş cranium (Denizli, Turkey). Comptes Rendus Palevol 11, 89-95. 
Vialet, A., Guipert, G., Alçiçek, M.C., de Lumley, M.-A., 2014. La calotte crânienne d’Homo erectus archaïque de Kocabaş, Bassin de Denizli, Anatolie, Turquie. L’Anthropologie 118, 74-107.

Vialet, A., Prat, S., Wils, P., Alçiçek, M.C., 2018. The Kocabaş hominin (Denizli Basin, Turkey) at the crossroad of Eurasia: New insight from morphometrical and cladistical analyses. Comptes Rendus Palevol 17, 17-32.

Voinchet, P., Bahain, J.J., Falguères, C., Laurent, M., Dolo, J.M., Despriée, J., Gageonnet, R., Chaussé, C., 2004. ESR dating of quartz extracted from Quaternary sediments. Application to fluvial terraces system of northern France. Quaternaire 15, 135-141.

Wagner, C.W., 1964. Ostracods as environmental indicators in Recent and Holocene estuarine deposits of The Netherlands. Pubblicazioni della Stazione zoologica di Napoli 33(suppl.), 480-495.

Welter-Schultes, F.W., 2012. European non-marine molluscs, a guide for species identification. Planet Poster Editions, Göttingen.

Wesselingh, F.P., 2007. Long-Lived Lake Molluscs as Island Faunas: A Bivalve Perspective. In: Renema, W. (Ed.), Biogeography, Time, and Place: Distributions, Barriers, and Islands. Springer, Dordrecht, pp. 275-314.

Wesselingh, F.P., Alçiçek, H., Magyar, I., 2008. A Late Miocene Paratethyan mollusc fauna from the Denizli Basin (southwestern Anatolia, Turkey) and its regional palaeobiogeographic implications. Geobios 41, 861-879.

Westaway, R., 1993. Neogene evolution of the Denizli region of western Turkey. Journal of Structural Geology 15, 37-53.

Yassini, I., 1986. Ecology, paleoecology and stratigraphy of ostracodes from Upper Pliocene and Quaternary deposits of the South Caspian Sea, North Iran. Lake Illawarra Management Committee, 78 p.

Zeitoun, V., 2000. Adequation between environmental shifts and human speciations during the Plio-Pleistocene. Comptes Rendus de l'Académie des Sciences de Paris, Ser. IIA 2(330), 161-166.

Zettler, M.L., Frankowski, J., Bochert, R., Rohner, M., 2004. Morphological and ecological features of Theodoxus fluviatilis (Linnaeus, 1758) from Baltic brackish water and German freshwater populations. Journal of Conchology 38, 305-316.

Zhu, Z., Dennell, R., Huang, W., Wu, Y., Qiu, S., Yang, S., Zhigio, R., Yamei, H., Jiubing, X., Jiangwei, H., Ouyang, T., 2018. Hominin occupation of the Chinese Loess Plateau since about 2.1 million years ago. Nature 559, 608. 


\section{Figure captions}

Fig. 1. A. Location of the Denizli Basin. B. Geological map of the Denizli Basin with indication of travertine units exposed (based on Sun, 1990).

Fig. 2. 3D re-establishment of anatomical connections of the fragments which composed the Kocabaş cranium once the left part of the supra-orbital torus was completed by using mirrorimaging of the right part (Vialet et al., 2018).

Fig. 3. A. Southern corner of the Faber quarry with an overview of the section composed of four units. B-D. Detailed pictures of Unit 4 (Upper Conglomerates), outcropping at the northern end of the western wall (37²51'58.77' 'N, 29²0'12.94'’ E), with position of micropalaeontological samples within clay intercalations. E. Layer with recrystallized mollusc shells within the Upper Conglomerates.

Fig. 4. Stratigraphy and lithology of the Kocabaş succession, locating the studied fossil assemblages and detailing Unit 4 (Upper Conglomerates).

Fig. 5. Most relevant ostracod species from the Kocabaş section. All valves of ostracods belong to adult individuals; LV: left valve; RV: right valve; all pictures are taken on external lateral view except when otherwise stated. A, B. Candona neglecta. A: LV; B: RV. C, D. Lineocypris sp. C: LV; D: RV. E, F. Prinocypris zenkeri. E: LV; F: RV. G, H. Cypria sp. G: Carapace LV; H: RV internal view. I, J. Darwinula stevensovi. I: LV; J: RV. K, L. Cyprideis torosa. K: LV; L: RV. M, N. Cyprideis sp. 1. M: LV; N: RV. O, P. Tyrrhenocythere pontica. O: LV; P: RV. Q, R. Tyrrhenocythere ex. gr. bailovi. Q: LV; R: RV. Scale bar: $500 \mu \mathrm{m}$.

Fig. 6. Most relevant ostracod species from the Kocabaş section. All valves of ostracods belong to adult individuals; LV: left valve; RV: right valve; all pictures are taken on external lateral view except when otherwise stated. A, B. Tyrrhenocythere sp. 1. A: LV; B: RV. C-E. Amnicythere aff. pediformis. C: LV; D: RV; E: Carapace, ventral view. F-H. Amnicythere multituberculata. F: RV; G: LV; H: Carapace, dorsal view. I-N. Loxoconchissa (Loxocaspia) aff. reticulate. I: RV, female; J: LV, female; K: Carapace, dorsal view, female; L: LV, male; M: RV, male; N: Carapace, dorsal view, male. O-T. Loxoconchissa (Loxocaspia) sp. O: LV, 
female; P: RV, female; Q: carapace dorsal view, female; R: LV, male; S: RV, male; T: Carapace, dorsal view, male. Scale bar: $500 \mu \mathrm{m}$.

Fig. 7. Mollusc species from the Kocabaş section. A. RGM.961870, Theodoxus sp., $\mathrm{W}=$ $3.1 \mathrm{~mm}$. B, C. RGM.961869, Theodoxus sp., $\mathrm{W}=3.1 \mathrm{~mm}$. D. Theodoxus sp., cast in situ. Width of image: $\sim 2 \mathrm{~cm}$. E. Theodoxus spp., cast in situ. Width of image: $\sim 4 \mathrm{~cm}$. F. RGM.961871a, Melanopsis sp., $\mathrm{H}=10.9$ mm. G. Accumulation of Melanopsis sp. from large block of travertine at quarry entrance. H largest specimen: 15 mm. H. RGM.961871b, Melanopsis sp., $\mathrm{H}=14.3$ mm. I-K. RGM.961873, Bithynia cf. pseudemmericia, $\mathrm{H}=5.0 \mathrm{~mm}$. L, M. RGM.961874, Bithynia sp., H = 5.3 mm. N, O. RGM.961875, Bithynia sp., $\mathrm{H}=$ 8.3 mm. P, Q. RGM.961876, Bithynia sp., H = 5.9 mm.

Fig. 8. Mollusc species from the Kocabaş section. A, B. RGM.961877, Islamia cf. pseudorientalica, $\mathrm{H}=3.5$ mm. C. RGM.961878, ?Islamia sp., $\mathrm{H}=5.5$ mm. D-F. RGM.961880, Islamia cf. anatolica, H = 3.3 mm. G, H. RGM.961881, Islamia cf. anatolica, H = 3.5 mm. I, J. RGM.961882, Islamia cf. anatolica, H = 4.2 mm. K. RGM.961883, Falsipyrgula cf. carinata, $\mathrm{H}=5.7$ mm. L, M. RGM.961884, Hydrobiidae sp. 1, H = 2.8 mm. N, O. RGM.961885, Hydrobiidae sp. 2, H = 2.8 mm. P, Q. RGM.961886, Hydrobiidae sp. 2, $\mathrm{H}=6.7$ mm. R, S. RGM.961887, Hydrobiidae sp. 2, H = 3.4 mm. T. RGM.961888, Lymnocardiinae sp., H = 2.5 mm. U, V. RGM.961889, Dreissena sp., L = 3.1 mm. W, X. RGM.961890, Dreissena sp., L = $6.7 \mathrm{~mm}$.

Fig. 9. Freshwater brachyuran crabs (Potamidae). A. Complete specimen FRC-18-19 from Aydin Mermer, dorsal view. B. Strongly disarticulated specimen FRC-18-20 from Aydin Mermer, probable exuvia, dorsal view. C. Disarticulated specimen EGE-PV-2945 fossilized in a small natural cavity formed inside the travertines from Faber, dorsal view. D. Subcomplete specimen FRC-18-10 fossilized in a small natural cavity formed inside the travertines from Kömürcüoğlu, dorsal view. E. Disarticulated specimen FRC-18-37 from Alimoğlu, frontal view of the carapace and scattered pereiopods, probable exuvia. F. Specimen EGE-PV-2956 from Dalmersan, strongly encrusted carapace, dorsal view. G. Specimen FRC-18-102 from Alimoğlu (Izmir), strongly encrusted specimen associated with plant roots. Scale bars: $2 \mathrm{~cm}$. 
Fig. 10. Vertebrate remains from the Upper Travertine from the Kocabaş section and surrounding quarries. A. cf. Varanus, vertebral column. B. Archidiskodon meridionalis meridionalis, PV-1469, saw cut of incomplete upper M2-3 (Lebatard et al., 2014; Boulbes et al., 2014). C. Equus cf. altidens/E. cf. mygdoniensis and E. cf. apolloniensis, PV-1460, distal portion of left metacarpal (Lebatard et al., 2014; Boulbes et al., 2014). D. Equus cf. apolloniensis, FR-18-40, left upper M3. E. Stephanorhinus cf. etruscus, PV-1470, saw cut of left mandible with P4-M3. F. Metacervoceros rhenanus, FA-1, saw cut of left antler (Lebatard et al., 2014; Boulbes et al., 2014). G. Arvernoceros sp., left antler. H. Cervalces (Libralces) ex gr. minor-gallicus, PV-1470, incomplete right antler beam with skull fragment in the travertine block (Lebatard et al., 2014; Boulbes et al., 2014). I. Palaeotragus sp., PV1477, incomplete ossicone (Lebatard et al., 2014; Boulbes et al., 2014). J. Gazella sp., PV1478, saw cut of left mandible. K. Bovinae gen. indet., KO-2, saw cut of left lower M1 (incomplete) and M2 (Erten et al., 2005). L. Lagurodon arankae, left lower M1 (modified from the original drawing of Gercek Saraç). M. Mimomys ex. gr. reidi-pusillus, left lower M3 (modified from the original drawing of Gercek Saraç).

Fig. 11. Depositional model of the Kocabaş palaeolake. 